\title{
Krzysztof Żebryk
}

Uniwersytet Mikołaja Kopernika, Torun

k.zebryk@doktorant.umk.pl

ORCID: https://orcid.org/0000-0003-2519-5548

\section{O powstaniu ex lege służebności gruntowej o treści służebności przesyłu - uwagi na tle orzecznictwa Sądu Najwyższego}

http://dx.doi.org/10.12775/SIT.2019.014

\section{Wprowadzenie}

Uregulowanie stanu prawnego urządzeń przesyłowych na nieruchomościach, które nie stanowią przedmiotu własności czy użytkowania wieczystego przedsiębiorców przesyłowych, jest aktualnym i istotnym problemem zarówno prawnym, jak i społecznym $-z$ uwagi na skalę zjawiska ${ }^{1}$. Strony inicjujące spory dotyczące posadowienia urządzeń przesyłowych na nieruchomościach często nie uwzględniają uwarunkowań historyczno-prawnych, w jakich doszło do umieszczenia urządzeń. Tym samym narażają się na ryzyko nieuwzględnienia roszczenia $\mathrm{w}$ przypadku ustalenia prawnego charakteru korzystania $z$ nieruchomości.

${ }^{1}$ Dane z Portalu Orzeczeń Sądów Powszechnych wskazują dla hasła „służebność przesyłu” ponad 2500 orzeczeń, a dla hasła „zasiedzenie służebności przesyłu” ponad 1500 orzeczeń, http://orzeczenia.ms.gov.pl (dostęp: luty 2018 r.). 
Warunkiem ustanowienia służebności przesyłu albo uwzględnienia roszczeń wynikających $z$ bezumownego korzystania $z$ nieruchomości jest, w pewnym uproszczeniu, uprzednie ustalenie, czy właściciel urządzeń przesyłowych korzysta $z$ cudzej nieruchomości bez tytułu prawnego. Stwierdzenie, że przedsiębiorca przesyłowy posiada tytuł prawny, będzie skutkować oddaleniem powództwa o usuniecie urządzeń, o wynagrodzenie za bezumowne korzystanie z nieruchomości albo wniosku o ustanowienie albo o zasiedzenie służebności ${ }^{2}$. Przeszkodą do uwzględnienia wskazanych roszczeń może być m.in. ustalenie istnienia tytułu prawnego nieruchomości, funkcjonującego $z$ mocy prawa - taką możliwość dostrzegało zarówno dawniejsze, jak i bieżące orzecznictwo Sądu Najwyższego ${ }^{3}$.

Przedmiot dalszych rozważań stanowi poszukiwanie odpowiedzi na pytanie, czy w wyniku uwłaszczenia przedsiębiorstw państwowych na majątku państwowym ${ }^{4} \mathrm{w}$ okresie transformacji ustrojowej lat 1989-1991 doszło do obciążenia nieruchomości Skarbu Państwa z mocy prawa trwałymi i skutecznymi erga omnes tytułami prawnymi (służebnościami) do nieruchomości, na których posadowione były w czasie uwłaszczenia urządzenia przesyłowe?

${ }^{2}$ Wskazać tu należy przykładowo, że wykonywanie uprawnień w zakresie wynikającym $z$ decyzji wydanej na podstawie art. 35 ust. 1 i 2 Ustawy $z$ dnia 12 marca 1958 r. o zasadach i trybie wywłaszczania nieruchomości (tekst jednolity: Dz.U. z 1974 r. Nr 10, poz. 64 ze zm.), stanowiącej tytuł prawny do ich wykonywania, nie prowadzi do nabycia przez zasiedzenie służebności gruntowej odpowiadającej treści służebności przesyłu (uchwała Składu Siedmiu Sędziów SN z dnia 8 kwietnia 2014 r., III CZP 87/13, Legalis nr 797812); podobnie $z$ mocy przepisów szczególnych nie istnieje możliwość ustanowienia służebności przesyłu w pasie drogowym drogi publicznej (postanowienie SN z dnia 27 kwietnia 2017 r., II CSK 412/16, Legalis nr 1640723).

${ }^{3}$ Zob. uchwała Składu Siedmiu Sędziów SN - zasada prawna - z dnia 18 czerwca 1991 r., III CZP 38/91, Legalis nr 27374; wyrok SN z dnia 21 maja 2015 r., IV CSK 514/14, Legalis nr 1310268; postanowienie SN z dnia 12 maja 2016 r., IV CSK 509/15, Legalis nr 1488827; postanowienie SN z dnia 12 maja 2016 r., IV CSK 510/15, Legalis nr 1472995; postanowienie SN z dnia 2 marca 2017 r., V CSK 356/16, Legalis nr 1650961.

${ }^{4}$ Przepisy prawa cywilnego, w szczególności art. 128 k.c., w okresie przed nowelizacją k.c., która weszła w życie 1 lutego 1989 r., nie operowały pojęciem własności Skarbu Państwa, lecz pojęciem socjalistycznej własności ogólnonarodowej (państwowej). 


\section{Sytuacja przedsiębiorstw przesyłowych przed transformacją ustrojową}

Dobrym przykładem na opisanie sytuacji własnościowo-organizacyjnej, w jakiej znajdowały się przedsiębiorstwa przesyłowe przed transformacją ustrojową lat 1989-1990, będzie branża elektroenergetyczna ${ }^{5}$. W tamtym czasie cały majątek sieciowy, w tym sieci energetyczne i infrastruktura sieciowa, pozostawał w zarządzie zakładów energetycznych, ale stanowił własność państwową . Zakłady energetyczne miały status państwowych osób prawnych, działających $\mathrm{w}$ formie przedsiębiorstw państwowych, a ich ustrój określała Ustawa z 25 września 1981 r. o przedsiębiorstwach państwowych ${ }^{7}$.

Odnotować należy, że już po wejściu w życie Kodeksu cywilnego z 1964 r. toczyła się żywa dyskusja nad charakterem zasady jednolitego funduszu własności państwowej ${ }^{8}$. Zastanawiano się, czy państwowym osobom prawnym mogą przysługiwać cywilne mająt-

${ }^{5}$ Do 31 grudnia 1988 r. na terenie Polski funkcjonowało 5 elektroenergetycznych przedsiębiorstw państwowych zgrupowanych we Wspólnocie Energii i Węgla Brunatnego: Centralny Okręg Energetyczny w Warszawie, Zachodni Okręg Energetyczny w Poznaniu, Północny Okręg Energetyczny w Bydgoszczy, Wschodni Okręg Energetyczny w Radomiu i Południowy Okręg Energetyczny w Katowicach. Na podstawie zarządzenia nr 57 Prezesa Rady Ministrów z 30 grudnia 1988 r. (P-330-62-88) od 1 stycznia 1989 r. w wyniku podziału Okręgów Energetycznych powołano jako samodzielne przedsiębiorstwa państwowe 33 zakłady energetyczne.

${ }^{6}$ Zgodnie $\mathrm{z}$ brzmieniem przepisu art. 128 § 1 k.c. do 30 stycznia 1989 r. socjalistyczna własność ogólnonarodowa (państwowa) przysługiwała niepodzielnie Państwu. Z kolei przepis art. $128 \S 2$ k.c. stanowił, że „w granicach zdolności prawnej państwowe osoby prawne wykonywają w imieniu własnym względem zarządzonych przez nie części mienia ogólnonarodowego uprawnienia płynące z własności państwowej”.

7 Dz.U. z 1981 r. Nr 24, poz. 122 ze zm.

${ }^{8}$ Zob. S. Grzybowski, Sytuacja prawna mienia ogólnonarodowego $w$ kodeksie cywilnym, „Państwo i Prawo” 1965, z. 4; J. Gwiazdomorski, Zasada jedności państwowej własności socjalistycznej a osobowość prawna przedsiębiorstw państwowych, „Państwo i Prawo” 1967, z. 4-5; idem, Czy zasada jedności własności państwowej obowiązuje $w$ stosunkach cywilnoprawnych, „Państwo i Prawo" 1973, z. 7. 
kowe prawa podmiotowe. Pojawiały się głosy, że w obrocie cywilnoprawnym można poniekąd mówić o tym, że „państwo występuje w stosunkach cywilnoprawnych jako Skarb Państwa bezpośrednio, pośrednio zaś poprzez inne państwowe osoby prawne, zwłaszcza

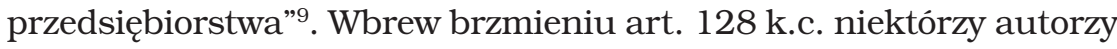
opowiadali się za tym, że przedsiębiorstwa państwowe mają pełen zakres praw podmiotowych w obrocie cywilnoprawym. Prezentowano trzy koncepcje, $z$ których pierwsza zakładała, że przedsiębiorstwo ma prawo rzeczowe lub prawo podobne do prawa rzeczowego. Według drugiej przedsiębiorstwu przysługiwało prawo podmiotowe sui generis. Z kolei według trzeciej koncepcji uznawano przedsiębiorstwo za powiernika mienia ogólnonarodowego ${ }^{10}$.

Wejście w życie Ustawy z 25 września 1981 r. o przedsiębiorstwach państwowych dostarczyło kolejnych argumentów za uznaniem podmiotowości tychże przedsiębiorstw w zakresie stosunków cywilnoprawnych. W nowej ustawie wyposażono przedsiębiorstwa we wszystkie uprawnienia w stosunku do mienia ogólnonarodowego będącego $\mathrm{w}$ jego dyspozycji $\mathrm{z}$ wyjątkiem uprawnień wyłączonych przepisami ustawowymi (art. 38 ust. 3), zapewniając tym samym im ochronę (art. 38 ust. 2). Rozszerzeniu uległa swoboda w zbywaniu środków trwałych oraz ustanawianiu ograniczonych praw rzeczowych (art. 43 ust. 1). Także możliwość żądania przez przedsiębiorstwo wyrównania szkody doznanej z powodu wykonania decyzji organu sprawującego nadzór (art. 58) podkreślała samodzielność tego podmiotu gospodarczego.

Orzecznictwo Sądu Najwyższego sprzed 1989 r. nie potwierdza jednak pełnej podmiotowości przedsiębiorstw państwowych. Prezentowano w nim raczej stanowisko kompromisowe, według którego „państwowe osoby prawne w stosunkach "zewnętrznych"” występują tak jak podmioty własności i innych praw podmiotowych, natomiast w stosunku "wewnętrznym» wobec państwa nie mogą

9 S. Szer, Prawa podmiotowe państwowych osób prawnych, „Państwo i Prawo" 1967, z. 6, s. 885.

${ }^{10}$ Por. J. Frąckowiak, Majątek przedsiębiorstwa państwowego ze szczególnym uwzględnieniem praw do nieruchomości wchodzących w jego skład, „Państwo i Prawo” 1990, z. 4, s. 41. 
mu przeciwstawić żadnych skutecznych praw własnych"11. Jako przykład dominującej linii orzeczniczej SN warto przywołać wyrok z 8 maja 1979 r. ${ }^{12}$, w którym orzeczono, że „przepis art. 128 par. 1 k.c., stanowiąc iż socjalistyczna własność ogólnonarodowa (państwowa) przysługuje niepodzielnie państwu, wyraża zasadę jedności własności państwowej, w związku z czym nabywcą i właścicielem nieruchomości wynikającym z konkretnej umowy zawartej przez przedsiębiorstwo państwowe jest Skarb Państwa, a nie przedsiębiorstwo, które w granicach wynikających $z$ postanowień art. 128 $\S 2$ k.c. - wykonuje w imieniu własnym względem przydzielonego mu mienia uprawnienia płynące $z$ własności państwowej”.

Sygnalizowane wyżej poglądy doktryny i judykatury w okresie przed transformacją ustrojową nie doprowadziły ostatecznie do przełamania zasady jednolitej własności państwowej i uznania, że przedsiębiorstwa państwowe mogły nabywać prawa podmiotowe. Świadczą jednak o tym, że dostrzegano ścisły związek między działalnością przedsiębiorstw państwowych a mieniem im powierzonym. Uchwalenie ustawy o przedsiębiorstwach państwowych odbierano jako proces upodmiotowienia przedsiębiorstw państwowych przez dążenie do wyposażenia ich w instrumenty prawne, ,aby od strony formalnoprawnej mogły one występować jako rzeczywiste podmioty obrotu prawno-gospodarczego, a nie tylko jako ogniwa obrotu gospodarczego" ${ }^{13}$.

${ }^{11}$ T. Dybowski, Własność Skarbu Państwa i państwowych osób prawnych $w$ świetle nowego art. 128 k.c., „Państwo i Prawo” 1990, z. 4, s. 31.

${ }^{12}$ Wyrok SN z dnia 8 maja 1979 r., I CR 137/79, Legalis nr 21470; zob. też: wyrok SN z dnia 27 marca 2008 r., III CSK 329/07, Legalis nr 127060; postanowienie SN z dnia 5 czerwca 2009 r., I CSK 495/08, Legalis nr 265754; postanowienie SN z dnia 16 września 2009 r., II CSK 103/09, Legalis nr 285208; postanowienie SN z dnia 22 października 2009 r., III CSK 38/09, Legalis nr 303954.

13 T. Dybowski, Własność, s. 32; podobnie S. Włodyka, Założenia regulacji prawnej mienia ogólnonarodowego, „Państwo i Prawo” 1987, nr 10, s. 74. 


\section{Zmiany legislacyjne okresu transformacji ustrojowej w kontekście uwłaszczenia przedsiębiorstw państwowych}

Z dniem 1 lutego 1989 r. zmieniono przepis art. 128 k.c. i zniesiono zasadę jednolitej własności państwowej ${ }^{14}$. W znowelizowanym brzmieniu przepis ten stanowił, iż „własność ogólnonarodowa (państwowa) przysługuje Skarbowi Państwa albo innym państwowym osobom prawnym”. Zagadnienie, jaki wpływ wywarła zmiana art. 128 k.c. na zakres i charakter uprawnień państwowych osób prawnych, przysługujących im do części mienia ogólnonarodowego pozostającego w ich posiadaniu, stanowiło przedmiot interesującej dyskusji w doktrynie prawa i analiz w orzecznictwie sądowym ${ }^{15}$. Zasadniczo wskazać należy, że starły się dwa poglądy. Niektórzy autorzy, w tym Tomasz Dybowski, stanęli na stanowisku, że „wolą ustawodawcy było nie tylko otwarcie na przyszłość możliwości nabywania przez państwowe osoby prawne mienia, lecz również «uwłaszczenie» ich z dniem wejścia w życie ustawy tymi składnikami mienia, które w tym dniu były w ich zarządzie" ${ }^{16}$. Oznaczałoby to automatyczne, $z$ mocy samej zmiany przepisu art. 128 k.c., przejście praw podmiotowych Skarbu Państwa na przedsiębiorstwa państwowe. Polemikę z tym poglądem przedstawił Zbigniew Radwański, który uznał, że „sam art. 128 k.c. (znowelizowany) nie przekształca ex lege stosunków własnościowych"17.

${ }^{14}$ Zmiana art. 128 k.c. mocą art. 1 ust. 1 Ustawy z dnia 31 stycznia 1989 r. o zmianie ustawy Kodeks cywilny (Dz.U. Nr 3, poz. 11).

${ }^{15} \mathrm{Na}$ temat motywów nowelizacji art. 128 k.c. oraz kwestionowania przez ograny administracji publicznej uwłaszczenia państwowych osób prawnych na skutek zmiany art. 128 k.c. mocą ustawy z dnia 31 stycznia 1989 r. pisze J. Brol, Kierunki zmian w kodeksie cywilnym, „Przegląd Ustawodawstwa Gospodarczego" 1990, nr 5-6, s. 83.

${ }_{16}$ T. Dybowski, Własność, s. 33.

17 Z. Radwański, W sprawie skutków prawnych nowelizacji art. 128 k.c., „Państwo i Prawo” 1990, z. 4, s. 53. 
W kierunku wskazanym przez tego ostatniego autora podążył ustawodawca. Świadczy o tym zmiana Ustawy z 29 kwietnia 1985 r. o gospodarce gruntami i wywłaszczaniu nieruchomości ${ }^{18}$ skutkująca przyznaniem $z$ mocy prawa przedsiębiorstwom państwowym użytkowania wieczystego odnośnie do pozostających w ich zarządzie nieruchomości, a w przypadku budynków - prawa własności ${ }^{19}$. Wskazane zmiany powodują, że uprawnione jest stwierdzenie, iż z dniem 5 grudnia 1990 r. doszło do uwłaszczenia przedsiębiorstw państwowych na nieruchomościach, co nie budzi co do zasady wątpliwości prawnych ${ }^{20}$. Uwłaszczenie wynika tu z jasnej normy praw-

18 Dz.U. z 1985 r. Nr 22, poz. 99.

19 Kluczowy dla uwłaszczenia państwowych osób prawnych na nieruchomościach przepis art. 2 ust. 1 Ustawy z dnia 29 września 1990 r. o zmianie ustawy o gospodarce gruntami i wywłaszczaniu nieruchomości stanowi, że „grunty stanowiące własność Skarbu Państwa lub własność gminy (związku międzygminnego), z wyłączeniem gruntów Państwowego Funduszu Ziemi, będące w dniu 5 grudnia 1990 r. w zarządzie państwowych osób prawnych innych niż Skarb Państwa, stają się z tym dniem z mocy prawa przedmiotem użytkowania wieczystego. Nie narusza to praw osób trzecich. Uprawnienia państwowych gospodarstw rolnych do będących w dniu 5 grudnia $1990 \mathrm{r}$. w ich zarządzie gruntów stanowiących własność Skarbu Państwa reguluje odrębna ustawa”. $Z$ kolei $z$ mocy przepisu art. 2 ust. 2 omawianej noweli „budynki i inne urządzenia oraz lokale znajdujące się na gruntach, o których mowa w ust. 1, stanowiących własność Skarbu Państwa lub własność gminy (związku międzygminnego), będących w dniu 5 grudnia 1990 r. w zarządzie państwowych osób prawnych, stają się z tym dniem z mocy prawa własnością tych osób. Nabycie własności przez te osoby następuje odpłatnie, jeżeli obiekty te nie były wybudowane lub nabyte ze środków własnych tych osób lub ich poprzedników prawnych”. Następnie w art. 2 ust. 3 ustawy z dnia 29 września 1990 r. ustalono, że „nabycie prawa użytkowania wieczystego gruntów, o których mowa w ust. 1, oraz własności budynków, innych urządzeń i lokali, o których mowa w ust. 2, stwierdza się decyzją wojewody w odniesieniu do nieruchomości stanowiących własność Skarbu Państwa lub decyzją zarządu gminy w odniesieniu do nieruchomości stanowiących własność gminy”.

${ }^{20}$ Pewne kontrowersje budził podział na obiekty nabyte lub wybudowane ze środków własnych uwłaszczanych podmiotów, które przechodziły na ich własność nieodpłatnie, i na obiekty nabyte lub wybudowane $z$ innych środków, których przejście miało następować odpłatnie, na co wskazuje M. Bednarek, Przeobrażenia stosunków własnościowych a problemy legislacyjne, „Państwo i Prawo" 1992, z. 5, s. 25. Z kolei E. Gniewek krytycznie odniósł się do faktu uwłaszczenia prawem użytkowania wieczystego gruntów, a nie przekazaniem 
nej, która $z$ jednej strony stanowiła podstawę materialnoprawną przejścia praw, a $z$ drugiej określała ramy proceduralne tego przejścia, w szczególności wskazując na konieczność uzyskania decyzji potwierdzających nabycie praw do nieruchomości. Mechanizm ten powodował, że państwowe osoby prawne dysponowały decyzjami, które stanowiły podstawę ujawnienia praw w księgach wieczystych.

Kolejnym krokiem ku uwłaszczeniu przedsiębiorstw państwowych było wejście w życie z dniem 7 stycznia 1991 r. Ustawy z 20 grudnia 1990 r. o zmianie ustawy o przedsiębiorstwach państwowych ${ }^{21}$. Na podstawie przepisu art. 1 pkt 9 ppkt a i b tej ustawy w art. 42 ust. 2 ustawy zmienianej skreślono wyrazy „stanowiącym część mienia ogólnonarodowego" oraz cały ust. 3, a także zmieniono numerację ustępów. Zmieniono więc przepis, który stanowił, że „przedsiębiorstwo, gospodarując wydzielonym mu i nabytym mieniem stanowiącym część mienia ogólnonarodowego, zapewnia jego ochronę”, nadając mu brzmienie: „przedsiębiorstwo, gospodarując wydzielonym mu i nabytym mieniem, zapewnia jego ochronę". Uchylono także przepis art. 38 ust. 3: „przedsiębiorstwo państwowe wykonuje wszelkie uprawnienia w stosunku do mienia ogólnonarodowego będącego w jego dyspozycji”.

W przypadku uwłaszczenia przedsiębiorstw na majątku innym niż nieruchomości wątpliwości nasuwa sama konstrukcja normy prawnej, która ma stanowić podstawę uwłaszczenia. Jak wskazano wyżej, przepisy art. 2 ust. 1 i 2 ustawy z 29 września 1990 r. wyraźnie stanowiły o przyznaniu praw do nieruchomości i ich części składowych. Tymczasem zmiany w ustawie o przedsiębiorstwach państwowych takiej wyraźnej dyspozycji nie zawierają, ograniczając się do usunięcia treści o gospodarowaniu częścią mienia ogólnonarodowego. Ponadto, o ile uwłaszczenie $z$ mocy art. 2 ust. 1 i 2 r. ustawy z 29 września 1990 r. stwierdzane było deklaratywną decyzją administracyjną ${ }^{22}$, o tyle nabycie $z$ mocy przepisów ustawy

ich na własność (E. Gniewek, O przekształceniach prawa do nieruchomości państwowych osób prawnych, „Państwo i Prawo” 1991, z. 12, s. 66).

${ }^{21}$ Dz.U. z 1991 r. Nr 2, poz. 6.

22 Zob. art. 2 ust. 3 ustawy z dnia 29 września 1990 r.; zob. także art. 200 
z 20 grudnia 1990 r. nie było potwierdzane tego rodzaju aktem. $\mathrm{Z}$ tego powodu uwłaszczone $\mathrm{w}$ ujęciu materialnym na majątku ruchomym i prawach przedsiębiorstwa państwowe na płaszczyźnie formalnej czy proceduralnej nie uzyskiwały dokumentów stwierdzających przejście praw. Ma to istotne znaczenie dla ustalenia sytuacji własnościowej sieci urządzeń przesyłowych (w rozumieniu art. 49 k.c.) oraz uwarunkowań prawnych ich położenia na nieruchomościach osób trzecich, w tym Skarbu Państwa. Doszło więc do sytuacji, w której przedsiębiorstwa przesyłowe zostały uwłaszczone na stanowiących dotąd własność państwową ruchomościach, w tym urządzeniach przesyłowych, a jednocześnie urządzenia te pozostały na nieruchomościach stanowiących własność Skarbu Państwa. Nie stworzono jednak ustawowych ram prawnych służących uregulowaniu tej sytuacji.

W sprawie skutków prawnych dokonanej $z$ dniem 31 stycznia 1989 r. zmiany art. 128 k.c. wypowiedział się Sąd Najwyższy w uchwale $z 18$ czerwca $1991 \mathrm{r}^{23}$, której nadano moc zasady prawnej. Sąd Najwyższy uznał, że „z chwilą wejścia w życie ustawy z dnia 31 stycznia 1989 r. o zmianie ustawy - kodeks cywilny [...] zniesiona została zasada, że jedynie Skarbowi Państwa może przysługiwać prawo własności mienia państwowego, w wyniku czego państwowe osoby prawne uzyskały zdolność prawną w zakresie nabywania składników majątkowych na własność. Zmiana art. 128 k.c. dokonana tą ustawą nie spowodowała przekształcenia przysługujących państwowym osobom prawnym - na mocy przepisów Kodeksu cywilnego i ustaw szczególnych - uprawnień do części mienia ogólnonarodowego, pozostających w ich zarządzie w dniu wejścia w życie wymienionej ustawy. Przekształcenie zarządu w odniesieniu do gruntów stanowiących własność Skarbu Państwa lub gminy - w prawo użytkowania wieczystego, zaś w odniesieniu do budynków, innych urządzeń i lokali znajdujących się na tych gruntach - w prawo własności, nastąpiło na podstawie

ust. 1 Ustawy z dnia 21 sierpnia 1997 r. o gospodarce nieruchomościami (tekst jednolity: Dz.U. z 2016 r. poz. 2147 ze zm.).

${ }^{23}$ Uchwała SN z dnia 18 czerwca 1991 r., III CZP 38/91, Legalis nr 27374. 
ustawy z dnia 29 września 1990 r. o zmianie ustawy o gospodarce gruntami i wywłaszczaniu nieruchomości [...], a w odniesieniu do innych składników majątkowych - w prawo własności nastąpiło na podstawie ustaw określających ustrój majątkowy państwowych osób prawnych".

$Z$ punktu widzenia przedmiotu niniejszego artykułu znaczenie ma końcowa treść tezy cytowanej uchwały. Ustawą określającą ustrój majątkowy przedsiębiorstw państwowych była ustawa o przedsiębiorstwach państwowych, zmieniona ustawą z 20 grudnia 1990 r. Tym samym SN uznał, że na skutek zmiany ustawy o przedsiębiorstwach państwowych przedsiębiorstwa te uzyskały prawo własności składników majątkowych innych niż nieruchomości i ich części składowe, stanowiących dotąd własność Skarbu Państwa.

Pomimo dostrzeganych niedoskonałości ustawy z 20 grudnia $1990 \mathrm{r}^{24}{ }^{24}$ orzecznictwie Sądu Najwyższego ${ }^{25}$ przyjęto, że właśnie z mocy tej ustawy $z$ dniem 7 stycznia 1991 r. doszło do uwłaszczenia przedsiębiorstw państwowych na majątku państwowym pozostającym w ich zarządzie. W odniesieniu do przedsiębiorstw przesyłowych oznacza to w szczególności nabycie własności urządzeń przesyłowych. Jednakże ani przepisy Ustawy z 20 grudnia 1990 r. o zmianie ustawy o przedsiębiorstwach państwowych, ani brzmienie uchwały SN z 18 czerwca 1991 r. in fine nie wskazuje, że uwłaszczenie obejmowało również przyznanie prawa służebności i do korzystania $z$ nieruchomości Skarbu Państwa, na których były posadowione urządzenia przesyłowe.

Forma i treść nowelizacji ustawy o przedsiębiorstwach państwowych wskazuje na to, że celem uwłaszczenia było to, aby istniejące w dacie uwłaszczenia składniki majątkowe, dotąd stanowiące przedmiot praw podmiotowych (przede wszystkim własności) Skarbu Państwa, a pozostające w zarządzie przedsiębiorstw państwowych, uległy przekształceniu w przedmiot wyłącznych praw podmiotowych przedsiębiorstw państwowych. Podobnie uchwała SN z 18 czerwca

${ }^{24}$ Szerzej na temat problemów legislacyjnych na tle przeobrażeń własnościowych w pierwszych latach po transformacji ustrojowej pisze M. Bednarek, Przeobrażenia, s. 25-26.

${ }^{25}$ Zob. przypis nr 3. 
1991 r. odwołuje się do „przekształcenia zarządu [...] w odniesieniu do innych składników majątkowych - w prawo własności”. W tym kontekście warto zwrócić uwagę, że państwowe przedsiębiorstwa przesyłowe zarządzały nie nieruchomościami państwowymi, na których posadowione były urządzenia przesyłowe, lecz tylko tymi urządzeniami. W związku $z$ tym przekształcenie zarządu w prawo podmiotowe na podstawie Ustawy z 20 grudnia 1990 r. o zmianie ustawy o przedsiębiorstwach państwowych w rozumieniu uchwały SN z 18 czerwca 1991 r. mogło dotyczyć wyłącznie uzyskania własności urządzeń przesyłowych. Uwłaszczenie nie mogło natomiast prowadzić do powstania nowego prawa, które przed uwłaszczeniem nie istniało, nie pozostawało w zarządzenie przedsiębiorstwa i tym samym nie mogło ulec przekształceniu.

Za aprobatą tezy o uwłaszczeniu ex lege przedsiębiorstw państwowych na innych prawach majątkowych niż prawa do nieruchomości przemawia szereg argumentów, do których zaliczyć należy to, że już od lat 60. XX w. w doktrynie dostrzegano potrzebę wyposażenia przedsiębiorstw państwowych w prawa do majątku pozostającego w ich zarządzie i służącego im do prowadzenia działalności. Postulaty te nie pozostały bez częściowego choćby odzewu prawodawcy, czego przejawem było uchwalenie ustawy z 1981 r. o przedsiębiorstwach państwowych, która w realiach zasady jednolitej własności państwowej co prawda nie doprowadziła do uwłaszczenia przedsiębiorstw, ale wskazała kierunki zmian. W konsekwencji w okresie transformacji ustrojowej lat 1989-1990 doszło do zniesienia zasady jednolitej własności państwowej oraz przyznania przedsiębiorstwom państwowym praw do nieruchomości. Wola ówczesnego prawodawcy była więc jednoznacznie ukierunkowana na oderwanie państwowych osób prawnych w sensie majątkowym od Skarbu Państwa. Skoro więc ustawodawca zdecydował się na przekazanie państwowym osobom prawnym nieruchomości, to tym bardziej jego wolą było przekazanie im innych praw majątkowych, w szczególności dotyczących ruchomości. Brak jednak jakichkolwiek argumentów, aby przy okazji uwłaszczenia na prawach majątkowych miałoby dojść do wykreowania nowych, nieistniejących wcześniej praw przedsiębiorstw państwowych wobec Skarbu Państwa, takich jak służebności obciążające nieruchomości państwowe. 


\section{Powstanie ex lege służebności w orzecznictwie Sądu Najwyższego}

Prezentowana przez Sąd Najwyższy w ostatnich latach linia orzecznicza ${ }^{26}$ opierała się na przywołanej uchwale $z 1991 \mathrm{r}^{27}{ }^{2}$ tezie, że „w wyniku majątkowego usamodzielnienia przedsiębiorstw państwowych w postaci ich uwłaszczenia w odniesieniu do urządzeń przesyłowych, uwłaszczenie to miało ten skutek, iż powodowało nie tylko przekształcenie przysługującego przedsiębiorstwom prawa zarządu urządzeń przesyłowych w prawo ich własności (w dniu 7 stycznia 1991 r.). Doszło także do przekształcenia tego tytułu prawnego we właściwe prawo podmiotowe o treści, $z$ której wynika uprawnienie do dalszego korzystania $z$ nieruchomości będących własnością Skarbu Państwa, na których umiejscowione zostały urządzenia energetyczne. Prawem powstającym w wyniku przekształcenia tytułu do korzystania $z$ nieruchomości państwowych w zakresie niezbędnym do eksploatacji urządzeń uzyskanych na własność i posadowionych na tych nieruchomościach była - w poprzednim stanie prawnym - służebność gruntowa o treści odpowiadającej służebności przesyłu. Skoro możliwe było umowne nabycie albo zasiedzenie takiej służebności przed wejściem w życie przepisów art. 3051 i n. k.c., to taka służebność mogła też powstać ex lege jako prawny skutek uwłaszczenia osoby prawnej. Takie ograniczone prawo rzeczowe jest skuteczne wobec kolejnych właścicieli obciążonej nim nieruchomości gruntowej”28.

Ukształtowana w latach 2015-2017 linia orzecznicza Sądu Najwyższego, oparta na koncepcji powstania służebności ex lege na skutek zmian legislacyjnych okresu transformacji ustrojowej, odwołuje się wprost do przepisów Ustawy z 20 grudnia 1990 r. o zmianie ustawy o przedsiębiorstwach państwowych, jako podstawy nabycia przez przedsiębiorstwa państwowe własności urządzeń przesyłowych

${ }^{26}$ Zob. przypis nr 3.

27 Zob. przypis nr 23.

${ }^{28}$ Postanowienie SN z dnia 12 maja 2016 r., IV CSK 509/15, Legalis nr 1488827. 
posadowionych na gruntach stanowiących własność Skarbu Państwa i służebności gruntowych odpowiadających treścią służebności przesyłu $^{29}$. Stanowisko to spotkało się z krytyczną oceną doktryny prawa, w której podnoszono, że „znajduje wyłącznie oparcie w wykładni funkcjonalnej, której zastosowanie w analizowanej sytuacji budzi uzasadnione wątpliwości”30.

W istocie przywołana linia orzecznicza zasługuje na krytykę, albowiem - jak wykazałem we wcześniejszej części artykułu - ustawa o zmianie ustawy o przedsiębiorcach państwowych nie zawierała przepisu, który wprost lub w drodze wykładni innej aniżeli funkcjonalna pozwalałby na ustalenie podstawy prawnej powstania prawa podmiotowego o charakterze służebności. Sąd Najwyższy nietrafnie powołuje się na analogię, wskazując, że „skoro możliwe było umowne nabycie albo zasiedzenie takiej służebności [gruntowej o treści służebności przesyłu - K. Ż.] przed wejściem w życie przepisów art. 3051 i n. k.c., to taka służebność mogła też powstać ex lege jako prawny skutek uwłaszczenia osoby prawnej”. $Z$ tym stwierdzeniem SN nie można się zgodzić. Uwłaszczenie osoby prawnej na mocy ustawy o zmianie ustawy o przedsiębiorstwach państwowych w rozumieniu uchwały SN z 18 czerwca 1991 r. oznacza przekształcenie zarządu majątkiem Skarbu Państwa w prawo podmiotowe do tego majątku. Konstrukcja ta zakłada, że wygaszone zostało prawo podmiotowe Skarbu Państwa do składników majątkowych zarządzanych przez przedsiębiorstwo państwowe oraz sam zarząd przedsiębiorstwa państwowego, a w to miejsce powstało

${ }^{29}$ Zob.: postanowienie SN z dnia 12 maja 2016 r., IV CSK 510/15, Legalis nr 1472995; postanowienie SN z dnia 17 czerwca 2016 r., IV CSK 531/15, Legalis nr 1471871. Problem powstania służebności z mocy prawa pojawił się także na tle rozstrzygania przez SN zagadnienia, czy służebność przesyłu może być ustanowiona na prawie użytkowania wieczystego. Sąd Najwyższy w uchwale z dnia 16 maja 2017 r. (III CZP 101/16, Legalis nr 1591658) stwierdził, że użytkownik wieczysty nie może skutecznie żądać ustanowienia służebności przesyłu, jeżeli urządzenia przesyłowe - zainstalowane przez przedsiębiorstwo państwowe w okresie obowiązywania zasady jednolitej własności państwowej - znajdowały się na nieruchomości Skarbu Państwa przed oddaniem jej w użytkowanie wieczyste.

${ }^{30}$ K.A. Dadańska, Glosa do postanowienia Sądu Najwyższego z 12 maja 2016 r., IV CSK 509/15, „Orzecznictwo Sądów Polskich” 2017, nr 5, s. 39. 
prawo podmiotowe przysługujące przedsiębiorstwu państwowemu. Przedsiębiorstwo państwowe mogło zostać uwłaszczone tylko na prawie istniejącym w dacie uwłaszczenia i tylko na prawie, które przysługiwało Skarbowi Państwa i pozostawało w zarządzie przedsiębiorstwa państwowego. Służebności obciążające nieruchomości Skarbu Państwa w związku $z$ położeniem na nich urządzeń przesyłowych w dacie uwłaszczenia nie istniały. W myśl zasady nemo plus in alium iuris transferre potest quam ipse habet nie mogły więc zostać przeniesione na uwłaszczane przedsiębiorstwa. Ustawodawca mógł ustanowić na rzecz uwłaszczanych państwowych przedsiębiorstw przesyłowych nowe prawa podmiotowe o treści służebności przesyłu, które uprawniałyby do utrzymania urządzeń przesyłowych na nieruchomościach Skarbu Państwa i korzystania $z$ nich. $Z$ uwagi na zasady państwa prawa i numerus clausus ograniczonych praw rzeczowych wymagana byłaby tu wyraźna norma prawna, mająca swe źródło w ustawie.

Również w orzecznictwie sądów powszechnych analizowane zagadnienie budziło wciąż wiele wątpliwości, czego wyrazem było przedstawienie do rozstrzygnięcia składowi powiększonemu Sądu Najwyższego pytania prawnego: „czy uzyskanie na własność przez przedsiębiorstwo państwowe urządzeń przesyłowych, posadowionych na nieruchomościach należących wówczas do Skarbu Państwa, na podstawie ustawy z dnia 20 grudnia 1990 r. o zmianie ustawy o przedsiębiorstwach państwowych spowodowało uzyskanie przez to przedsiębiorstwo $z$ mocy prawa - jako prawa związanego z własnością urządzeń - służebności gruntowej o treści odpowiadającej służebności przesyłu obciążającego te nieruchomości?”31. Sąd Najwyższy, rozpoznając przytoczone zagadnienie prawne, przedstawił całkowicie odmienne zapatrywanie aniżeli prezentowane we wcześniejszych orzeczeniach. Uznał mianowicie, że „nabycie przez przedsiębiorstwo państwowe - na podstawie ustawy $z$ dnia 20 grudnia 1990 r. o zmianie ustawy o przedsiębiorstwach państwowych [...] - własności urządzeń przesyłowych posadowionych na nieruchomościach należących do Skarbu Państwa nie spowodowało

31 Postanowienie SN z dnia 16 lutego 2017 r., III CZP 100/16, Legalis nr 1575941. 
uzyskania przez to przedsiębiorstwo z mocy prawa służebności gruntowej o treści odpowiadającej służebności przesyłu obciążającej te nieruchomości”32.

Zaprezentowane przez Sąd Najwyższy w uchwale z 5 czerwca 2018 r. stanowisko oceniam co do zasady jako prawidłowe, acz niewolne od pewnych niekonsekwencji. Słusznie Sąd Najwyższy wskazał, że prezentowany we wcześniejszych postanowieniach ${ }^{33}$ pogląd, że „art. 1 pkt 9 ustawy z 20 grudnia 1990 r. o zmianie ustawy o przedsiębiorstwach państwowych był źródłem nabycia ex lege służebności gruntowej jest zbyt daleko idący”. SN podkreślił, że „nawet jeśli ustawodawca wprowadza do systemu prawnego przepis stwarzający w zakresie praw rzeczowych nowy stan prawny, jakim byłby przepis ustanawiający ex lege służebność gruntową, o treści odpowiadającej służebności przesyłu, czyni to w drodze wyjątku, który ma jednoznaczną podstawę prawną w ustawie; takiej podstawy, jak wskazano, nie ma w art. 1 pkt 9 u.z.u.p.p.”. W treści uzasadnienia uchwały z 5 czerwca 2018 r. SN wskazał też, że stanowisko zajęte w jego wcześniejszych postanowieniach wzbudza „wątpliwości z perspektywy zasady numerus clausus praw rzeczowych”. Stwierdzenie to oceniam jako bezsprzecznie słuszne, ale nie tylko w kontekście sposobu powstania prawa, jak czyni to SN, ale przede wszystkim w kontekście treści tego prawa. SN w analizowanej uchwale odnosi się wyłącznie do tego, że prawo nazywane służebnością gruntową o treści służebności przesyłu nie może powstać ex lege, bez oparcia w wyraźnym przepisie prawa. SN nie ma jednak zastrzeżeń do tego, że sama konstrukcja służebności gruntowej o treści służebności przesyłu, tj. takiej służebności gruntowej, dla której nie ma zindywidualizowanej nieruchomości władnącej, jest wątpliwa w świetle przywołanej zasady numerus clausus i jako taka powinna być poddana krytyce w nauce prawa ${ }^{34}$. Przeciwnie, SN wskazuje, że prawo rzeczowe o wskazanej treści może zostać

${ }^{32}$ Uchwała SN z dnia 5 czerwca 2018 r, III CZP 50/17, Legalis nr 1779436.

33 Zob. przypis nr 3.

${ }^{34}$ Zob. G. Matusik, Własność urzadzeń przesyłowych a prawa do gruntu, Warszawa 2013, s. 375 i nast.; B. Rakoczy, Zasiedzenie służebności przesyłu, Warszawa 2014, s. 187-192. 
stwierdzone w wyniku „zasiedzenia i to także na nieruchomościach Skarbu Państwa po okresie obowiązywania zasady jednolitej własności państwowej, jeżeli urządzenia przesyłowe zostały wniesione na tych nieruchomościach w okresie jej obowiązywania”.

Wątpliwości SN z perspektywy zasady numerus clausus praw rzeczowych powinny dotyczyć tego, że ustawie nie jest znana instytucja służebności gruntowej, dla której wbrew normie $z$ art. 285 § 2 k.c. nie zindywidualizowano nieruchomości władnącej. Sposób powstania takiej służebności gruntowej, niemieszczącej się w katalogu praw rzeczowych, ma znaczenie wtórne. Tym samym zapatrywanie Sądu Najwyższego, że wątpliwości w kontekście zasady numerus clausus praw rzeczowych budzi wyłącznie okoliczność powstania służebności ex lege, nie zaś treść tego prawa, nie jest trafne.

\section{Podsumowanie}

Jeszcze pod rządami zasady jednolitej własności państwowej dostrzegano potrzebę wyposażenia przedsiębiorstw państwowych we własny majątek i prawa niezbędne do prowadzenia ich działalności. W wyniku transformacji ustrojowej z dniem 31 stycznia 1989 r. doszło do zmiany przepisu art. 128 k.c. i zniesienia zasady jednolitej własności państwowej, stanowiącej barierę dla usamodzielnienia majątkowego państwowych osób prawych. Zmiana ta stanowiła pierwszy krok do ich uwłaszczenia na zarządzanych dotąd składnikach mienia ogólnonarodowego.

Sytuacja, w jakiej znalazły się przedsiębiorstwa przesyłowe po zniesieniu zasady jednolitej własności państwowej, bez wątpienia uzasadniała ich usamodzielnienie majątkowe wobec Skarbu Państwa w jak najpełniejszym zakresie, w tym poprzez ustalenie zasad korzystania z nieruchomości Skarbu Państwa. Dogodnym instrumentem prawnym byłaby tu służebność. Nie istniały przy tym przeszkody, aby analogicznie do uwłaszczenia państwowych osób prawnych na nieruchomościach na podstawie Ustawy z 29 września 1990 r. o zmianie ustawy o gospodarce gruntami i wywłaszczaniu nieruchomości, ustawodawca stworzył ramy prawne dla powstania odpowiedniej służebności. W świetle przeprowadzonej analizy 
przepisów prawa, dorobku doktryny i judykatury nie ma jednak wątpliwości, że wymaganej akcji legislacyjnej nie było.

Sąd Najwyższy w orzecznictwie $z$ lat 2015-2017 stał na stanowisku, że uwłaszczeniu przedsiębiorstw państwowych w trybie ustawy o zmianie ustawy o przedsiębiorstwach państwowych towarzyszyło powstanie ex lege służebności gruntowych o treści odpowiadającej służebności przesyłu na ówczesnych nieruchomościach Skarbu Państwa, na których znajdowały się urządzenia przesyłowe. Jednakże w uchwale z 5 czerwca 2018 r. Sąd Najwyższy zajął stanowisko odmienne, uznając, że wejście w życie ustawy z 20 grudnia 1990 r. nie spowodowało powstania $z$ mocy prawa służebności gruntowych o treści odpowiadającej służebności przesyłu. Zgodzić należy się z tym najnowszym stanowiskiem Sądu Najwyższego. Do powstania ograniczonych praw rzeczowych może dojść wyłącznie w sposób wskazany w ustawie, a przepisy ustawy z 20 grudnia 1990 r. o zmianie ustawy o przedsiębiorstwach państwowych nie stanowią samoistnej podstawy powstania służebności.

Prezentowaną w analizowanym orzecznictwie SN z lat 2015-2017 argumentację, że przedsiębiorstwa państwowe uzyskały ex lege służebności gruntowe o treści służebności przesyłu jako skutek uwłaszczenia dokonanego mocą Ustawy z 20 grudnia 1990 r. o zmianie ustawy o przedsiębiorstwach państwowych, oceniam jednoznacznie jako nietrafną. Uznaję, że przeniesienie praw podmiotowych na uwłaszczane przedsiębiorstwa państwowe mogło dotyczyć tylko tych praw, które w dacie uwłaszczenia istniały, przysługiwały Skarbowi Państwa i pozostawały w zarządzie przedsiębiorstwa państwowego. Służebność obciążająca nieruchomości Skarbu Państwa w związku z położonymi na nich urządzeniami przesyłowymi nie spełnia żadnego $z$ wskazanych warunków. W związku $z$ tym ustanowienie służebności obciążających nieruchomości Skarbu Państwa nie mogło nastąpić na podstawie przepisów ustawy o zmianie ustawy o przedsiębiorstwach państwowych, lecz wymagało odrębnej regulacji ustawowej, która jednak nie nastąpiła. 


\section{STRESZCZENIE}

O powstaniu ex lege służebności gruntowej

o treści służebności przesyłu - uwagi na tle orzecznictwa

Sądu Najwyższego

Inicjując postępowania sądowe dotyczące skutków prawnych posadowienia urządzeń przesyłowych na nieruchomościach, strony często nie uwzględniają uwarunkowań historyczno-prawnych, w jakich doszło do umieszczenia urządzeń przesyłowych na nieruchomościach, a tym samym narażają się na ryzyko oddalenia powództwa albo wniosku w związku z ustaleniem prawnego charakteru korzystania $z$ nieruchomości. Przeszkodą dla uwzględnienia wskazanych roszczeń może być m.in. ustalenie, że przedsiębiorca przesyłowy nabył $z$ mocy prawa trwały i skuteczny erga omnes tytuł prawny do nieruchomości obciążonej urządzeniem przesyłowym, którą to możliwość dostrzegało zarówno dawniejsze, jak i aktualne orzecznictwo Sądu Najwyższego. Artykuł wskazuje na przesłanki i podstawy prawne uwłaszczenia państwowych osób prawnych w związku z transformacją ustrojową, dokonaną w Polsce po 1989 r. W szczególności przedmiotem analizy jest to, czy państwowe przedsiębiorstwa przesyłowe $z$ chwilą przyznania im prawa własności urządzeń przesyłowych połączonych w sieć, uzyskały $z$ mocy prawa ograniczone prawa rzeczowe uprawniające je do korzystania $z$ nieruchomości, na których posadowione są urządzenia przesyłowe, a pozostających w czasie uwłaszczenia własnością Skarbu Państwa.

Słowa kluczowe: służebność przesyłu; służebność gruntowa o treści służebności przesyłu; powstanie ex lege ograniczonego prawa rzeczowego; uwłaszczenie przedsiębiorstw państwowych

\section{SUMMARY}

On the creation ex lege of a ground easement with a substance of a transmission easement - comments on the Supreme Court jurisprudence

On the beginning of legal proceedings regarding the legal consequences of setting up transmission equipment on real estate, the parties often do not 
take into account the historical and legal conditions in which the transmission devices were put on real estate. Thus, they expose themselves to the risk of dismissing an action in connection with determining the legal nature of the use of real estate. An obstacle to taking into account such claims may be, inter alia, determining that the energy company acquired by law the permanent and effective erga omnes title to the property burdened with the transmission device That was accepted both in the earlier and current case law of the Supreme Court. The article points to the premises and legal grounds for the enfranchisement of state legal persons, in connection with the political transformation that took place in Poland after 1989. In particular, the subject of the analysis is whether or not state transmission companies upon granting them ownership of transmission equipment connected in a network, obtained ex lege limited property rights authorizing them to use the real estate, on which transmission devices are located, and those were owned by the State Treasury in the time of enfranchisement.

Key words: a transmission easement; a ground easement with a substance of a transmission easement; creation of limited property right ex lege; enfranchisement of state companies

\section{BIBLIOGRAFIA}

Bednarek M., Przeobrażenia stosunków własnościowych a problemy legislacyjne, „Państwo i Prawo” 1992, z. 5.

Brol J., Kierunki zmian w kodeksie cywilnym, „Przegląd Ustawodawstwa Gospodarczego" 1990, nr 5-6.

Dadańska K.A., Glosa do postanowienia Sąu Najwyższego z 12 maja 2016 r., IV CSK 509/15, „Orzecznictwo Sądów Polskich” 2017, nr 5.

Dybowski T., Własność Skarbu Państwa i państwowych osób prawnych $w$ świetle nowego art. 128 k.c., „Państwo i Prawo” 1990, z. 4.

Frąckowiak J., Majątek przedsiębiorstwa państwowego ze szczególnym uwzględnieniem praw do nieruchomości wchodzacych $w$ jego skład, „Państwo i Prawo” 1990, z. 4.

Gniewek E., O przekształceniach prawa do nieruchomości państwowych osób prawnych, „Państwo i Prawo” 1991, z. 12.

Grzybowski S., Sytuacja prawna mienia ogólnonarodowego w kodeksie cywilnym, „Państwo i Prawo” 1965, z. 4.

Gwiazdomorski J., Czy zasada jedności własności państwowej obowiazuje w stosunkach cywilnoprawnych, „Państwo i Prawo” 1973, z. 7. 
Gwiazdomorski J., Zasada jedności państwowej własności socjalistycznej a osobowość prawna przedsiębiorstw państwowych, „Państwo i Prawo” 1967, z. 4-5.

Matusik G., Własność urządzeń przesyłowych a prawa do gruntu, Warszawa 2013.

Radwański Z., W sprawie skutków prawnych nowelizacji art. 128 k.c., „Państwo i Prawo” 1990, z. 4.

Rakoczy B., Domniemanie dobrej wiary przy zasiedzeniu służebności gruntowej o treści służebności przesyłu i zasiedzeniu służebności przesyłu, „Rejent” 2016, nr 6.

Rakoczy B., Zasiedzenie służebności przesyłu, Warszawa 2014.

Szer S., Prawa podmiotowe państwowych osób prawnych, „Państwo i Prawo” 1967, z. 6.

Włodyka S., Założenia regulacji prawnej mienia ogólnonarodowego, „Państwo i Prawo” 1987, nr 10. 